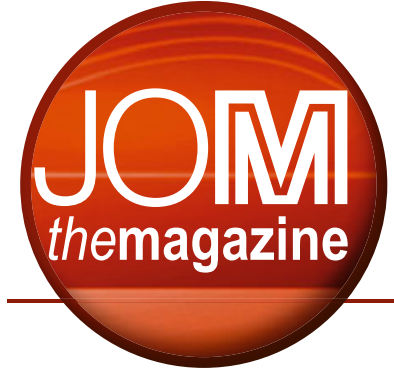

\section{TMS Board} of Directors

Elizabeth A. Holm

President

Professor, Carnegie Mellon

University

Wolfgang A. Schneider

Past President

Head, Research and

Development Center,

Hydro Aluminium Rolled

Products GmbH

Hani Henein

Vice President

Professor, University

of Alberta

\section{Robert W. Hyers}

Financial Planning Officer

Chief Technology Officer,

Boston Electrometallurgical

Corporation

\section{Srinivas Chada}

Director/Chair

Electronic, Magnetic \&

Photonic Materials Division

Component Packaging

Engineer, Schlumberger HFE

\section{Adrian C. Deneys}

Director/Chair

Extraction \& Processing

Division

Business Development

Manager, Praxair Inc.

\section{David H. DeYoung}

Director/Chair

Light Metals Division

Director, GPP Business

Technology, Alcoa Inc.

\title{
TMS board motions, minutes, and musings
}

\section{Board Spotlight: Securing the Financial Future of TMS}

\section{Robert W. Hyers}

What does TMS do for you? Perhaps you read the journals, participate in the general and specialty meetings, and know

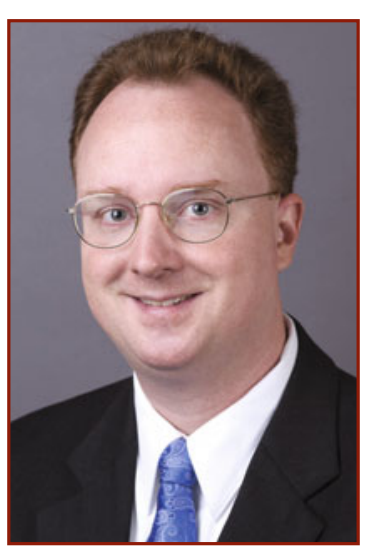

about the awards that recognize excellence from undergraduates to TMS Fellows. You may not think about what's going on behind the scenes. TMS is a Robert W. Hyers volunteer-centric society, with hundreds of professionals who volunteer their time to organize the symposia, present the papers, nominate the awardees, and contribute in countless other ways. TMS is also supported by 36 staff and numerous contractors and vendors who make it all work so smoothly.

This article is part of a series explaining the governance of the society and highlighting the roles of the volunteers. As Financial Planning Officer (FPO), I chair the Financial Planning Committee (FPC). The FPC consists of 5-6 volunteers, and is charged with "custodianship of all TMS financial resources," as detailed in the bylaws. To accomplish this responsibility, the FPC works closely with TMS's chief financial executive, Deputy Director Adrianne Carolla, who oversees all day-today and operational aspects of the finances of TMS.

The financial health of the society is detailed in the annual report, which is published in $J O M^{1}$ and on the TMS website. ${ }^{2}$ The major sources of revenue include those activities we all know so well-meetings, publications, and memberships. The major expense areas are similar-meetings, operations, publications, volunteer support, and membership.

TMS's Financial Management Policy ${ }^{3}$ governs the way the financial operations of the society are managed, including budgeting, investments, and accounting practices. An annual operating plan is prepared by the TMS staff, reviewed by the FPC, and approved by the Board of Directors. The Financial Management Policy requires that the annual operating plan provide for a surplus ("excess revenue") of $1 \%$ of the total operating revenue. This is analogous to a for-profit company targeting a net operating margin of $1 \%$.

The Financial Planning Committee also manages the investment of TMS's reserve fund and the TMS Foundation's endowment. (The retirement funds for staff are managed by the Retirement Committee, of which the FPO is a member.) The reserve fund serves as a buffer against emergencies such as the recent economic crisis, as a source of development funds for new products and services, and to support special initiatives of the TMS Board of Directors. Examples of these initiatives include recent efforts related to volunteerism, young professionals, core technologies, energy and environment, and materials and manufacturing. The endowment for the TMS Foundation supplements current-year donations in supporting the Foundation's charitable activities, while also providing a buffer against economic variations. TMS retains outside investment managers to monitor market conditions and recommend adjustments to the asset allocations in accordance with TMS's investment policy statement. $^{3}$

To ensure that the Financial Planning Committee and the membership have a complete and accurate picture of the 
finances of the society, TMS's accounts are audited annually by an independent firm. This firm is selected by, and reports to, the Audit Committee, which is chaired by the FPO. As reported in the Annual Report (p. 11), the last audit determined that "the financial statements ... presented fairly, in all material respects, the financial position of TMS." ${ }^{2}$ This is the best possible outcome of an audit.

To secure the continued financial well-being of the society, the Board of Directors made a number of revisions to the society's financial policies over the past few months. A clear definition of the concept of "operating reserves" gives a sharper picture of the resources available to the society to pursue new initiatives and weather adversity. The operating reserves are the difference between the reserves and liabilities of the society, analogous to an individual's net worth. It is now the operating reserve rather than the investment balance that has a target value set in the financial management policy. A modified retirement system for the staff will lead to more predictable and sustainable commitments for the society in this area. TMS staff has also adopted a set of best practices for management of cash flow that should result in improved return on the money reserved for short- term needs. Finally, the TMS Foundation was placed under an expanded Board of Trustees, with five new members appointed from the membership at large.

In conclusion, the financial state of TMS is good. Guided by our written policies, the dedicated staff and a large group of volunteer members work closely together to provide a firm foundation for the future of TMS and the professionals it serves in the minerals, metals, and materials communities.

\section{References:}

1. JOM 65 (9) (2013), front matter (no page numbers). 2. http://www.tms.org/Society/society.aspx, and choose 2012 Annual Report.

3. The financial management policy, investment policy statement, and related documents are available on the home page of the Financial Planning Committee in the members-only area of the TMS website. Log in at $h$ ttp://www.tms.org/administration /committees.aspx.

Robert Hyers is the Financial Planning Officer of TMS. He is Chief Technology Officer of the Boston Electrometallurgical Corporation and Professor, Department of Mechanical and Industrial Engineering, University of Massachusetts, Amherst. The TMS Financial Planning Committee members are: Brajendra Mishra of Colorado School of Mines; Thomas Battle of Midrex Technologies; Joy Forsmark of Ford Motor Company; and Hani Henein of the University of Alberta (TMS Vice President, ex officio).

\section{TMS Board Actions at a Glance}

\section{Meeting of October 27, 2013 \\ Membership:}

- Approved a new category of "honorary" membership reserved for individuals who are influential in the field, but who would be unlikely to join TMS. This would be extended by invitation from a committee.

- Approved the donation of a lifetime membership to the TMS Foundation for every individual cumulative lifetime donation of US\$20,000 or more.

Meetings:

- Requested staff to investigate and develop a recommendation concerning reducing conference no-shows by employing an early registration requirement.

- Approved the International Conference on Molten Slags, Fluxes and Salts as a TMSsponsored event to be held May 22-25, 2016 in Seattle, Washington. The lead organizer is Ramana Reddy, University of Alabama, Tuscaloosa.

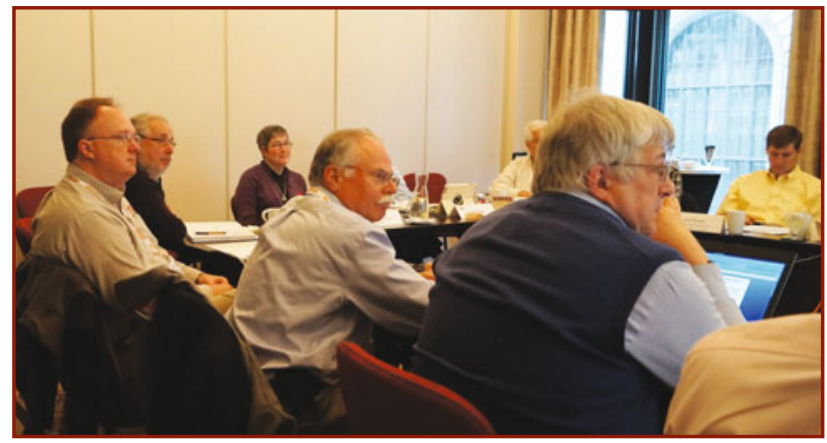

TMS Board of Directors

James C. Foley

Director/Chair

Materials Processing \&

Manufacturing Division

R\&D Manager, Los Alamos

National Laboratory

Rajiv S. Mishra

Director/Chair

Structural Materials Division

Professor, University of North Texas

David Alan Shifler

Director, Professional

Development

Program Officer, Office of

Naval Research

David F. Bahr

Director, Membership \&

Student Development

Head and Professor,

Materials Engineering,

Purdue University

Neville Moody

Director, Programming

Manager, Sandia National

Laboratories

Edward D. Herderick

Director, Public \&

Governmental Affairs

Director of $R \& D$, Rapid

Prototype + Manufacturing

Carl Cady

Director, Content

Development \&

Dissemination

Technical Staff, Los Alamos

National Laboratory

William J. "Jud” Ready

Director, Content

Development \&

Dissemination

Principal Research

Engineer, Georgia Institute

of Technology

James J. Robinson

Secretary

TMS Executive Director 